\title{
再帰型オートエンコーダを用いた振動データによるエ場設備の故障予測手法の 提案
}

朝日 翔太 ${ }^{* 1}$, 松井 彩華 ${ }^{* 1}$, 田村 哲嗣 ${ }^{* 1}$, 速水 悟 ${ }^{* 1}$, 井指 諒亮 ${ }^{* 2}$, 古川 輝 ${ }^{* 2}$, 内藤 孝昌 ${ }^{* 2}$

\section{Proposal of failure prediction method of factory equipment by vibration data with Recurrent} Autoencoder

\author{
Shota ASAHI ${ }^{* 1}$, Ayaka MATSUI ${ }^{*}$, Satoshi TAMURA*1, Satoru HAYAMIZU*1, \\ Ryosuke ISASHI $^{* 2}$, Akira FURUKAWA ${ }^{* 2}$ and Takayoshi NAITOU ${ }^{* 2}$ \\ ${ }^{*} 1$ Graduate School of Engineering, Gifu University \\ 1-1 Yanagido, Gifu-shi, Gifu 501-1193, Japan \\ ${ }^{*} 2$ KYB Corporation \\ World Trade Center Bldg. 11F, 2-4-1 Hamamatsu-cho, Minato-ku, Tokyo 105-6111, Japan
}

Received: 21 January 2020; Revised: 24 June 2020; Accepted: 12 October 2020

\begin{abstract}
In this paper, we propose a method to predict the failure of factory equipment by machine learning architectures using vibration data. We design the model so that we can predict robustly the failure of the equipment in advance. We use a Gaussian Mixture Model (GMM), a machine learning architecture, to calculate abnormality value which is used for the decision whether the state of the equipment is normal or abnormal by thresholding. We also use Long Short-Term Memory Autoencoder (LSTM-AE), one of the structures of the deep learning algorithm, for feature extraction. LSTMAE model learns both spatial and temporal patterns which are difficult to capture with conventional machine learning algorithms. We conducted the prediction experiment using vibration data obtained from actual mechanical equipment, to confirm our method can predict the failure more robust than conventional methods. From this experiment, we found that the abnormality value tended to exceed a threshold value before the actual failure, indicating that the failure can be predicted in advance by our method. Besides, when compared with conventional methods, we found that the transition of abnormality and the accuracy of failure prediction were almost the same in all cases, but we also showed that the proposed method has superiority on robustness compared to conventional methods about the transition of abnormality and the setting of the threshold.
\end{abstract}

Keywords : Anomaly detection, Failure prediction, Factory equipment, Signal processing, Vibration, Machine learning, Deep learning, Autoencoder,Recurrent Neural Network,GMM

1. 緒言

ここ数年でコンピュータの計算能力が格段に上昇し, AI・IoT 分野の研究開発は急速に発展した。一般社会にお いても, AI・IoT 技術を取り入れたシステム・機器が広く普及し始めている.このトレンドは産業分野においても 同様であり，工場設備や機械にセンサを取り付け，機械学習を応用した技術によりデータを解析することで，加 工異常の検出 (西田他, 2018) や機器の異常診断 (近藤, 2018) など, 異常検知をはじめとした課題解決を行う手法 およびシステムの研究開発は盛んに行われ始めている.

No.20-00020 [DOI:10.1299/transjsme.20-00020], J-STAGE Advance Publication date : 20 October, 2020

${ }^{* 1}$ 岐皁大学大学院 工学研究科 ( 7 501-1193 岐阜県岐阜市柳戸 1-1)

*2 KYB (株)（） 105-6111 東京都港区浜松町 2-4-1 世界貿易センタービル 11F）

E-mail of corresponding author: asahi@asr.info.gifu-u.ac.jp 
本研究は, 製造業の抱える課題の一つである, 工場内における機械および工場設備の故障の事前予測を，定期的 に取得した振動データにより行うシステムの開発を最終的な目標として取り組んでいる．産業分野における「異 常」は，不良品や異物混入など突発的に発生するような異常，劣化等に起因する機械設備の故障といった異常な ど，その種類は様々である (Chalapathy and Chawla, 2019). 本研究ではこのうち, 機械設備の劣化にともなう故障 をあらかじめ予測することを目的としている，本研究における故障予測モデルは，10 分おきに得られる振動デー タから, 正常時からどれだけ離れているかを示す指標 (以下, 異常度 (Abnormality) と記す) を算出する. 異常度は, その数值が高ければ高いほど異常に近い状態であるとする指標である (井手，杉山，2015). 異常度が一定期間異 常を示す閾值を超えた場合に，まもなく故障することを示すアラートを出す，というシステムの制作が最終的な 目的となる.

異常検知分野においては, Hotelling's T-square 法 (中塚他, 2018) や混合ガウス分布モデル (Hasegawa et al., 2017) のような，機械学習技術を用いた異常度算出が行われている。これらのモデルは，学習に用いるデータセット中 に含まれる異常データ群が, 正常データ群と比較して極少数であるか, もしくは正常データ群のみで構成されて いる，という仮定のもと，データ空間における正常データの分布を学習する．これにより，異常検知を行う際に は，入力データが学習した分布からどれだけ離れているかを算出することで，異常度を算出する．また，音声や 振動，センサデータなど，異常度算出モデルに入力するデータの次元数が大きい場合には，対象データの次元を 圧縮し，より小さい次元数でデータの持つ特徵を抽出する処理を行う場合がある.この次元圧縮には, 主成分分 析 (Abdi and Williams，2010)のような手法が用いられる場合が多い.

本論文では, 得られた振動データの時間ごとの推移から，機械学習および深層学習技術を用いた予測モデルを 用いて, 設備の故障を予測する手法を提案する. 提案する手法では, 機械学習手法の入力には加速度センサから 得られる振動データをパワースペクトルに変換したものを用いる．本手法における故障予測は，機械学習の一種 であり高度な学習が可能である深層学習の手法である, 再帰型オートエンコーダによる特徵抽出と, 機械学習に よる異常検知の手法である混合ガウス分布モデルによる異常度算出の 2 段階により行われる．本論文では，提案 手法に用いる機械学習手法と, 提案手法の詳細を紹介し，その後従来の異常検知手法と提案手法との故障予測精 度の比較，および使用する特徵量による故障予測精度を比較する検証実験を行い，故障予測手法の頑健性に関し て提案手法の優位性を示す. 本研究における「より頑健な故障予測モデル」について, 故障発生前の異常度が正 常時と比較してより明確に差が見られるかどうかに加え，設備の劣化の程度に伴い徐々に異常度が推移している かどうか，また故障が発生する一定期間前には故障がまもなく発生すると判定できるような異常度の推移が見ら れるかどうか，そして正常である期間内についても，異常時よりも十分低いものの徐々に異常度が上昇するよう な異常度を算出できているかどうか，という条件により該当するモデルであること，と定義する.

\section{2. 使用するデータについて}

本研究において故障予測を行う工場設備は, 自動車部品工場にて製品の搬送に用いられるチェーン式オーバー ヘッドトロリーコンベアである。このコンベアを駆動するモータ (図 1)に 3 軸加速度センサを設置し, 10 分おき に 10 秒間の振動データを自動的に取得した. 図 2 に示している今回設置した加速度センサは, 図 1 の左下にある ギア部の右手前部に設置した。チェーンコンベアの挙動に影響が無く，かつモータ振動以外の雑振動の影響を受 けにくい場所に設置している．使用するデータの条件を表 1 に示す．取得したデータのうち，実際に工場が稼働 していた 7 か月分の振動データを，後述する故障予測手法の学習および検証実験に用いている。この 7 か月中の イベントを図 3 のグラフにおいて，4本の縱線で示している. データの取得期間中に，一度チェーンの噛合い不良 に起因する異音が発生し，コンベアを停止したという事象が発生している(1). 本論文では，これ以降この事象 を「故障」として扱う。この故障発生 5 週間後にチェーンの交換を行い (2), チェーン交換 2 週間後にチェーン の初期伸びカットを行っている(3). また，チェーン初期伸びカット 2 週間後, 故障ではないがセンサ自体の位 置がずれるなどの原因により，センサデータの状態に変化が生じている(4). ただし，劣化に伴うチェーンの交 換は，3 年もしくは 4 年毎に実施している.

本論文では，本データのうちチェーンの初期伸びカット後の期間 (図中(2)-(3)の区間) を正常状態として扱う。ま た，図 3 には，この期間中における理想的な異常度の推移を曲線で示している. 図中の破線および実線を閾值と 


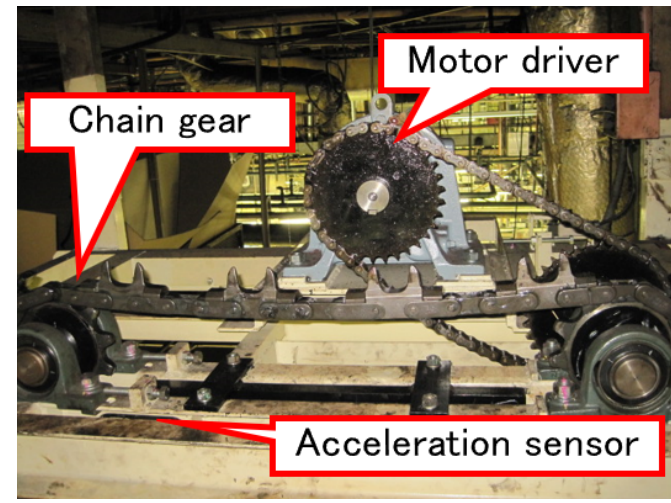

Fig. 1 A motor driver of chain conveyor.

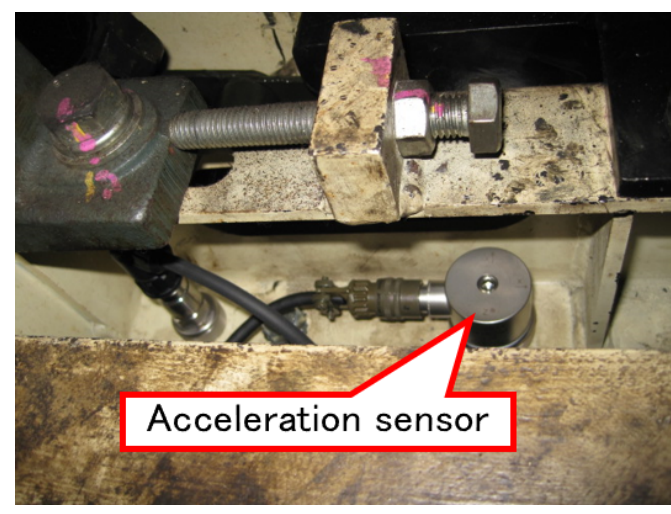

Fig. 2 The acceleration sensor installed on the motor drive. The sensor located on the right side of the gear at the lower left of the motor driver in Fig. 1.

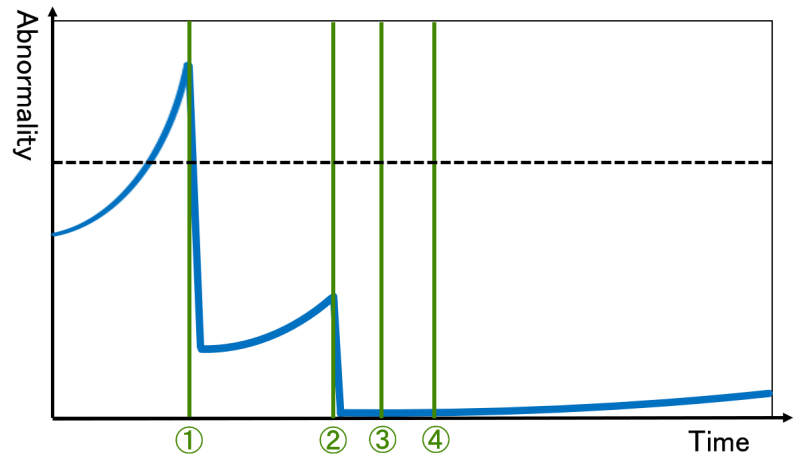

Fig. 3 Events during the data acquisition period and the ideal abnormality score. The actual failure occured in the period (1). The chain was exchanged in the period (2). The chain was cut the initial cut in the period (3). The data slightly altered in the period (4).

したとき, 異常度がこの閾値を故障が発生する前に設計することで, 故障予測を行うことが期待できる．実際の 機械設備においてチェーン交換の準備に要する期間の目安は 2 週間であるため, 本研究では, 2 週間程度前に異常 度が閾值に達しその後も上回り続けるように, 閾值を設定する.ただし, (1) から (2) の期間中は, チェーンを 交換せず劣化状態のチェーンを使用しているため, 故障直前よりは低いものの正常状態よりも高い異常度を保持 すると考えられる. さらに, (4) 以降の期間については, チェーン交換後間もない 3 か月分のデータであること を踏まえると，異常度はほぼ上昇せず，0に近い值での推移が理想的である.

本研究では, 3 軸加速度センサより得られた 3 方向データのうち, もっともコンベアの挙動と振動の傾向が近い ことがわかっている，鉛直 1 方向のデータを用いて故障予測モデルの構築を行う．また，本研究では 10 秒の振動 データをフレームと呼ばれる短いデータに分割し, 高速フーリエ変換 (Fast Fourier Transform; FFT) を行うことで 算出した，パワースペクトルを提案手法への入力データに使用する. 短い時間毎に分割しフレーム化したパワー スペクトルをモデルに連続的に入力することで，データの持つ時間次元と周波数次元の双方の情報をモデルに入 力することが可能である.

本データのサンプリング周波数は $12.8 \mathrm{kHz}$ であり, フレーム長 $500 \mathrm{~ms}$ で抽出した場合, パワースペクトルの次 元数は 6400 次元となる. 本研究では, このうち低周波帯域 320 次元のみを使用している.これは, チェーンコン ベアの搬送間隔が 0.67 秒であること, 高周波帯域における時間ごとの差が高周波帯域と比較して非常に小さいこ とから，コンベアより発せられる振動情報は低周波帯域に集中しているといえるためである.

\section{3. 機械学習および深層学習による特徵抽出手法}

実世界における製造現場において，異常が発生することはまれである (井手，杉山，2015)。すなわち，異常検 知や故障予測といったタスクにおいて, 対象となるデータセット中の異常データ群が, 正常データ群と比較して 
Asahi, Matsui, Tamura, Hayamizu, Isashi, Furukawa and Naitou,

Transactions of the JSME (in Japanese), Vol.86, No.891 (2020)

Table 1 Settings of vibration data aquired from the chain conveyor.

\begin{tabular}{c|c}
\hline Condition & Set value \\
\hline Time length per data & $10 \mathrm{~s}$ \\
\hline Number of data & 7452 \\
\hline Sampling frequency & $12.8 \mathrm{kHz}$ \\
\hline Frame length & $500 \mathrm{~ms}$ \\
\hline Frame shift & $250 \mathrm{~ms}$ \\
\hline Number of feature dimension & 320 \\
\hline
\end{tabular}

極少数，もしくは全く含まれていない場合が多い。このようなアンバランスなデータを扱う，機械学習による異 常検知手法には, Hotelling's T-square 法 (中塚他，2018), 混合ガウス分布モデル (Hasegawa et al., 2017) などが用 いられている. また, 本研究で用いているセンサデータから抽出したパワースペクトルなど, モデルの入力デー タの次元数が多い場合, 主成分分析をはじめとした次元圧縮手法を用いて有効な特徵量を抽出し，モデルに入力 する場合が多い。一方で，近年では特徵抽出手法に深層学習モデルを採用する研究も登場している.

本研究において提案する故障予測手法は，振動データから特徵抽出を行うモデルと抽出した特徵を用いて異常 度を算出するモデルの 2 つのモデルにより構成されている. 本章では, 特徵抽出を行う深層学習および機械学習 モデルとして採用している，再帰型オートエンコーダおよび主成分分析について説明する.

\section{$3 \cdot 1$ 再帰型ニューラルネットワークと再帰型オートエンコーダ}

本研究においては, 特徵抽出のための深層学習モデルに再帰型オートエンコーダを採用した。再帰型ニューラル ネットワーク (Recurrent Neural Network; RNN) は，テキストや音声をはじめとした連続データにおいて重要な情報 である，隣り合う時刻のデータの関係性を加味した学習を行うことができるネットワーク構造を有する (Srivastava et al., 2015). この構造を採用することで, 時系列データである振動データに対し，モデルが周波数情報だけでなく時間 方向における情報を学習することが期待できる. 本章では, RNN の一種である Long Short-Term Memory(LSTM), およびLSTM を用いた再帰型オートエンコーダについて詳説する.

\subsubsection{Long Short-Term Memory}

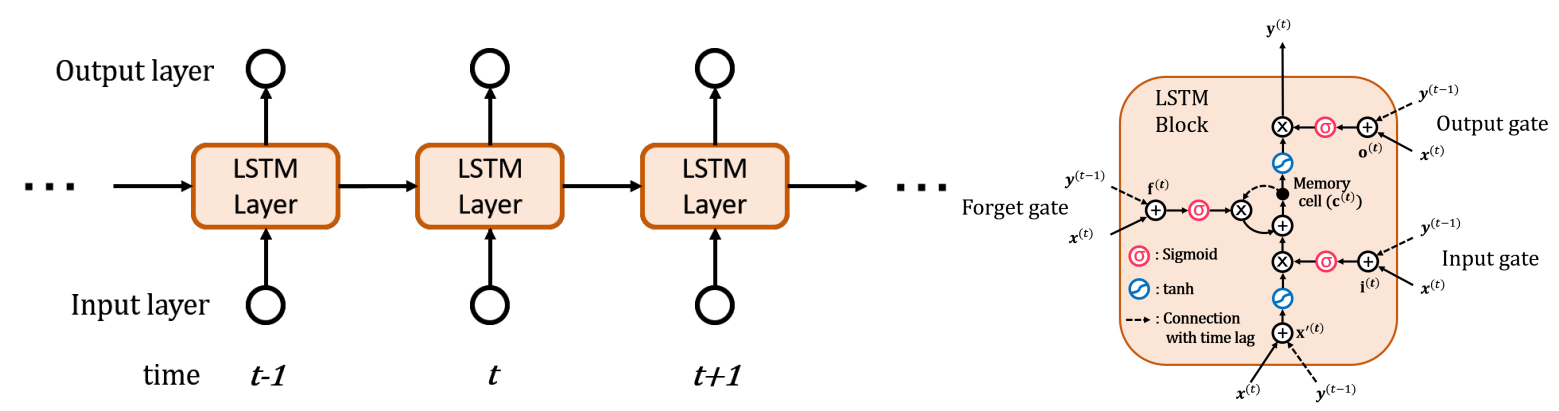

Fig. 4 The architecture of LSTM, expanded for temporal Fig. 5 The architecture of Gers' LSTM Block. With the gate direction. This architecture makes the model be able to learn both frequency and time information. mechanism of LSTM Block, an LSTM propagates only the necessary temporal information.

LSTM の一般的な構造 (展開形) を図 4 に示す。連続データの持つ時刻間の関係性を学習するため，時刻 $t$ にお ける RNNのノードは, 前の層の出力に加え 1 時刻手前, すなわち時刻 $t-1$ における RNNノードの情報をフィー ドバックする構造を持つ.これにより, データの学習や推論を行う際にデータの持つ連続的な情報を利用すること ができる，LSTM においては，時刻間の情報の伝播を行う RNN ノードに，LSTM ブロックと呼ばれるユニットを 採用する. LSTM は時代の変遷とともにより良い連続データの学習のため構造の工夫がなされてきているが，本 論文においては Gers らが提案した LSTM ブロック (Gers et al., 2000) を扱う. LSTM ブロックの内部構造を図 5 に 示す. LSTM ブロックは, input, output, forget と呼ばれる 3 種類のゲートとメモリセルと呼ばれるセルから構成 されている. 図 5 中に示した, 時刻 $t$ における LSTM ブロックへの入力 $\mathbf{x}^{(t)}$, input ゲートの出力 $\mathbf{i}^{(t)}$, forget ゲー トの出力 $\mathbf{f}^{(t)}$, メモリセルの出力 $\mathbf{c}^{(t)}$, output ゲートの出力 $\mathbf{o}^{(t)}$, そして LSTM ブロックの出力 $\mathbf{y}^{(t)}$ のベクトルは, 
それぞれ式(1), 式 (2), 式 (3), 式 (4), 式 (5), 式 (6) のように計算される. なお, 演算子 $\odot$ は, 対応するべクト ル要素同士の乗算を意味する. それぞれのゲートは時刻 $t-1$ からのフィードバックを用いる構造となっている. 入力信号と出力信号に対してそれぞれゲートを設置することで, 必要な情報のみを保持して学習することが可能 となる (Hochreiter and Schmidhuber, 1997)。 また忘却ゲートの設置により, 出力への影響が小さい情報を忘却する ことで，RNN 構造で発生する課題の一つである，誤差が消失してしまう現象を抑えることができ，長期間の学習 を行うことが可能となっている.

$$
\begin{aligned}
& \mathbf{x}^{(t)}=\tanh \left(W_{\mathbf{x}}, \mathbf{x}^{(t)}+R_{\mathbf{x}}, \mathbf{y}^{(t-1)}+\mathbf{b}_{\mathbf{x}}\right) \\
& \mathbf{i}^{(t)}=\operatorname{sigmoid}\left(W_{\text {in }} \mathbf{x}^{(t)}+R_{\text {in }} \mathbf{y}^{(t-1)}+\mathbf{b}_{\text {in }}\right) \\
& \mathbf{f}^{(t)}=\operatorname{sigmoid}\left(W_{\text {for }} \mathbf{x}^{(t)}+R_{\text {for }} \mathbf{y}^{(t-1)}+\mathbf{b}_{\text {for }}\right) \\
& \mathbf{c}^{(t)}=\mathbf{i}^{(t)} \odot \mathbf{x}^{(t)}+\mathbf{f}^{(t)} \odot \mathbf{c}^{(t-1)} \\
& \mathbf{o}^{(t)}=\operatorname{sigmoid}\left(W_{\text {out }} \mathbf{x}^{(t)}+R_{\text {out }} \mathbf{y}^{(t-1)}+\mathbf{b}_{\text {out }}\right) \\
& \mathbf{y}^{(t)}=\mathbf{o}^{(t)} \odot \tanh \left(\mathbf{c}^{(t)}\right)
\end{aligned}
$$

\subsection{2 再帰型オートエンコーダ}

オートエンコーダ (Autoencoder; AE) とは，ニューラルネットワーク構造を用いたアルゴリズムの一つであり， 主に次元圧縮を行う際に用いられる.図 6 に $\mathrm{AE}$ の構成例を示す．本アルゴリズムは中心となる中間層を基準に 対称な層数・次元数によるノードで構成される encoder-decoder モデルである. また，一般的に AEにおける層ご とのノード数は, 入力層が最も多く, 中心の中間層が最も少なくなるように設計される場合が多い. AE は, 学習 時には入力層と出力層に同じデータを用いて教師あり学習を行う．学習を行ったモデルを用いて次元圧縮を行う 際には，中心となる中間層のノード (図 6 における「中間表現」部)をモデルの出力層として扱うことで, 入力層 よりも少ないデータ次元の圧縮表現を獲得することが可能である．また，ニューラルネットワーク構造を用いる ため，主成分分析などでは難しい非線形な次元圧縮を行うことが可能である.

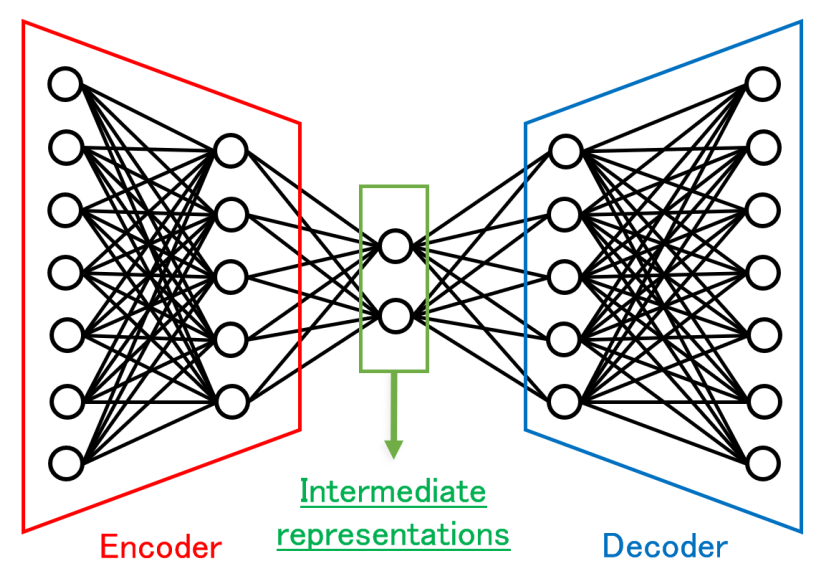

Fig. 6 The example of the architecture of Autoencoder (AE). AE has the encoder-decoder structure, and encoder and decoder are symmetrical in the layer direction.

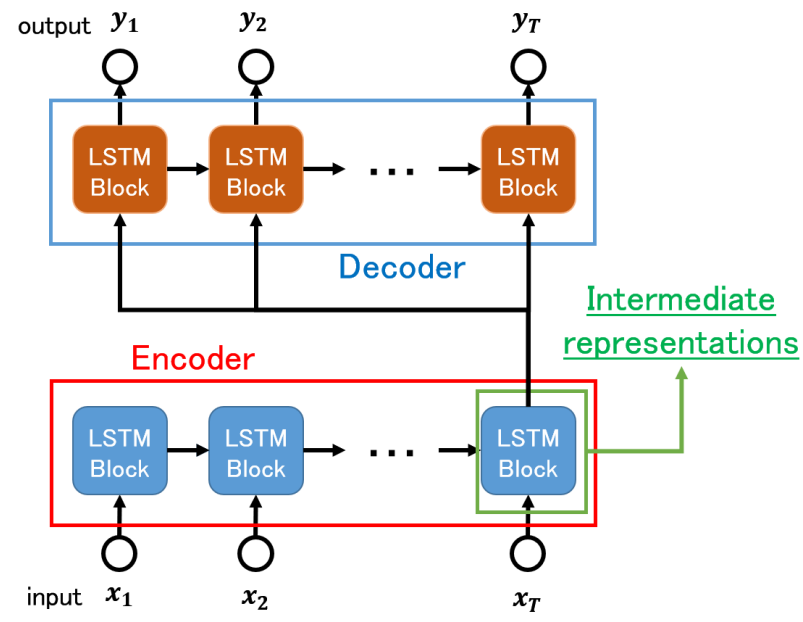

Fig. 7 The architecture of LSTM-Autoencoder. LSTM-AE is a structure in which nodes of encoder and decoder are replaced with LSTM Blocks.

本論文では, 中間表現部を含む中間層のノードを LSTM ブロックにより構成した，再帰型構造を持つ AEであ る LSTM-Autoencoder(LSTM-AE，図 7) を特徵抽出に用いる。これにより，AEによる非線形な次元圧縮に加え， 時系列情報も同時に次元圧縮の際の学習に用いるように設計する (Srivastava et al., 2015). このため, データの状 態をより忠実に保持したまま次元圧縮することが期待できる。ここで，本論文における LSTM-AE の中間表現は， Encoder 部のうち, 最後の入力が行われる時間ステップの LSTM ブロックの出力のことを指す．また図 7 に示して いる通り, Decoder 部における LSTM ブロックへの入力は, 前の時刻の出力と LSTM-AE の中間表現である. さ 
Asahi, Matsui, Tamura, Hayamizu, Isashi, Furukawa and Naitou,

Transactions of the JSME (in Japanese), Vol.86, No.891 (2020)

らに，Encoder 部と Decoder 部における LSTM ブロックは独立した異なる層であり，重みの共有などは行ってい ない.

\section{2 主成分分析}

主成分分析 (Principal Component Analysis; PCA) とは, 多次元データのもつ情報を，低次元データ空間に情報を 圧縮する手法の一つである。この手法は，解析するデータの持つ特徵量次元数が大きい場合に，その次元数を削 減するために用いられることが多い.PCA は, データの分散に着目し，新しい座標軸を求める手法である. はじ めに，入力データの特徵空間での分布において平均值をとる点を通り，分散の最も大きい方向の直線を第 1 主成 分の座標軸と定義する．続いて第 1 成分に直交し，かつ第 1 主成分に次いで分散が大きくなる方向の直線を第 2 主成分の座標軸と定義する. 同様に第 3 主成分，第 4 主成分， $\cdots$ と算出していく. 全情報量のうち，第 $m$ 主成分 が保持する元の情報量の割合を第 $m$ 主成分の寄与率とよぶ. また，第 1 主成分から第 $m$ 主成分までの寄与率の和 を, 第 $m$ 主成分までの累積寄与率とよぶ。この寄与率および累積寄与率を用いることで, 全情報量をどの主成分 まででどの割合で再現できているかを算出できる.

\section{4. 機械学習による異常度算出手法}

本章では，3 章において説明した手法により抽出した特徵量を用いて，異常度算出を行う手法について説明する. 本研究における異常度算出手法には, 従来の異常検知タスクにおいても多く用いられている機械学習手法である, Hotelling’s T-square 法と混合ガウス分布モデルの 2 手法を採用している.

\subsection{Hotelling's T-Square 法}

Hotelling’s T-square 法 (ホテリングの $T^{2}$ 法) とは，機械学習の概念を用いた異常度算出手法の一種であり，対象 となるデータセット中の異常データ群が, 正常データ群と比較して極少数であるか, もしくは正常データ群のみで あると仮定できる場合に利用される手法である (井手，杉山，2015). データセット $D$ は， $D=\left\{x^{1}, x^{2}, \ldots, x^{N}\right\}$ の $N$ 個のデータで構成され，各サンプル $x^{i}$ は $M$ 次元のベクトル $\left\{x_{1}^{i}, x_{2}^{i}, \ldots, x_{M}^{i}\right\}$ であるとする.このとき，データセッ ト $D$ 中のデータ群は, 次の式 (7) のように平均 $\mu$, 共分散行列 $\Sigma$ の多次元正規分布の確率密度関数 $N(\mathbf{x} \mid \mu, \Sigma)$ に従 うと仮定する.

$$
N(\mathbf{x} \mid \mu, \Sigma)=\frac{|\Sigma|^{-\frac{1}{2}}}{(2 \pi)^{\frac{M}{2}}} \exp \left\{-\frac{1}{2}(\mathbf{x}-\mu)^{\mathrm{T}} \Sigma^{-1}(\mathbf{x}-\mu)\right\}
$$

データセット $D$ 中には異常データ群はほぼ含まれていないという仮定より, 確率密度関数 $N(\mathbf{x} \mid \mu, \Sigma)$ は正常データ 群の状態モデルといえる. このとき, 未知のデータ x’ に対する異常度 $a\left(x^{\prime}\right)$ は, 次の式 (8) で算出できる.ここで, 式 (8) を展開し, 異常度の変化に大きな影響を及ぼさない定数項を削除することで, 式 (9) のように近似すること が可能である。一般的に Hotelling's T-square 法を用いる場合には，式 (9)により異常度を算出する場合が多い.

$$
\begin{aligned}
& a\left(x^{\prime}\right)=-\ln N\left(x^{\prime} \mid \mu, \Sigma\right) \\
& a\left(x^{\prime}\right)=\left(x^{\prime}-\mu\right)^{\mathrm{T}} \Sigma^{-1}\left(x^{\prime}-\mu\right)
\end{aligned}
$$

異常度 $a\left(\mathbf{x}^{\prime}\right)$ は, $D$ 中に出現する確率の高い正常データであれば小さな值を, 出現確率の低い異常データであれば 大きな值をとる。また，各データの特徵量次元数 $M$ に対して $D$ 中のデータ数 $N$ が十分に大きい場合には，異常 度 $a\left(\mathbf{x}^{\prime}\right)$ の分布は自由度 $M$, スケール因子 1 のカイ二乗分布に従う. 自由度 $k=1,2,4,8$ におけるスケール因子 1 のカイ二乗分布図を図 8 に示す。横軸が異常度, 縦軸が確率密度を示しており, 異常度が大きくなるにつれて確 率密度が小さくなるということがわかる. このことを利用し, 異常判定に使用する閾值 $a_{t h}$ は, 異常データの出現 率 $\alpha$ (ただし, $\alpha<1$ である) を設定することで, カイ二乗分布により算出する. そして, 未知データより算出し た異常度が，閾值 $a_{t h}$ を超えた場合に警報を出すことにより，正常・異常の判定を行う。 


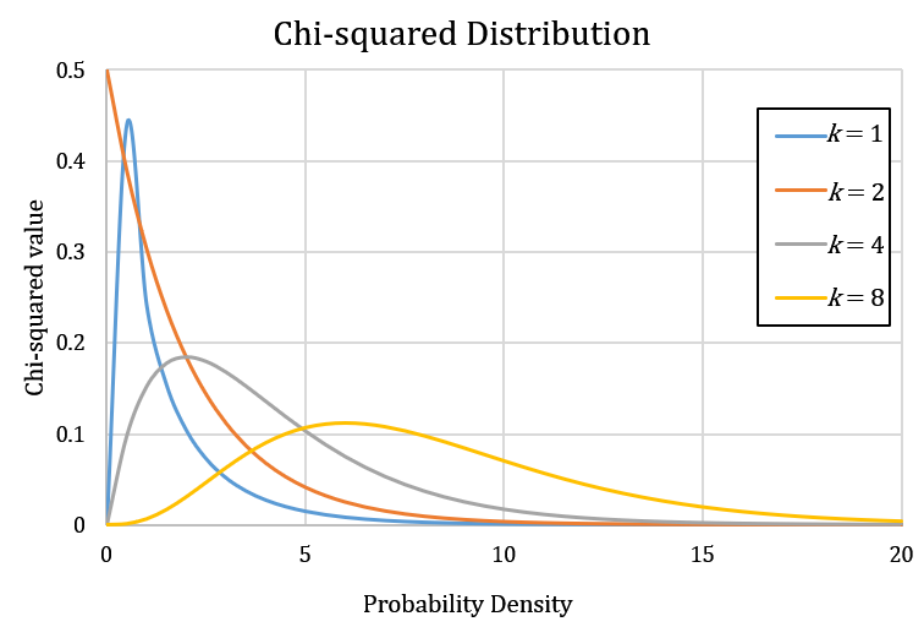

Fig. 8 The probability density function of Chi-squared distribution $\chi_{k}^{2}$ with digree of freedom $k=1,2,4,8$.

\section{2 混合ガウス分布モデル}

混合ガウス分布モデル (Gaussian Mixture Model; GMM) は, 本来は与えられたデータ群を複数のクラスタに分類 する，クラスタリングとよばれる分類に用いられる手法である (井手，杉山，2015). データセットを $K$ 個の正規 分布 $N\left(\mathbf{x} \mid \mu_{k}, \Sigma_{k}\right)$ (ただし， $\left.k=1,2, \ldots, K\right)$ の重畳により表現し，それぞれの正規分布クラスタに所属する確率をサ ンプルごとに算出することでクラスタリングを行う.

異常検知に用いる場合, 前節と同様, データセット $D$ に異常データ群がほぼ含まれていないという仮定に基づ いて混合ガウス分布モデルを学習し，モデルにより算出したデータごとの重み付き対数事後確率を異常度として 出力する．はじめに，混合ガウス分布の式を，データセットから最尤推定法により式 (10)のように算出する.

$$
p(\mathbf{x})=\sum_{k=1}^{K} \pi_{k} N\left(\mathbf{x} \mid \mu_{k}, \Sigma_{k}\right)
$$

式(10)において, $K$ を正規分布の数, $\pi_{k}$ は各正規分布の重みを示す. また， $\Sigma_{k=1}^{K} \pi_{k}=1$ である. その後, 予測す るサンプルに対して混合ガウス分布モデルにより重み付き対数確率 $p(\mathbf{x})$ を，式 (11) により算出する.

$$
p(\mathbf{x})=\ln \left(\sum_{k=1}^{K} \pi_{k} N\left(\mathbf{x} \mid \mu_{k}, \Sigma_{k}\right)\right)
$$

ここで，算出された重み付き対数事後確率は，そのデータが異常であればあるほど数值が小さくなる．本論文に おける異常度は, その数值が高いほど異常を示すものとするため, 本論文における GMMによる異常度 $a\left(\mathbf{x}^{\prime}\right)$ は式 (12)により算出する.

$$
a\left(\mathbf{x}^{\prime}\right)=-p\left(\mathbf{x}^{\prime}\right)
$$

また，GMMによる異常度の閾值については，異常データの出現率を $\alpha$ とした場合，全体の異常度の分布のう ち $(1-\alpha) * 100 \%$ となる值を閾值 $a_{t h}$ とおく.

\section{5. 提案手法の構造}

本章では, 本研究において提案する，3 章において説明した LSTM-AE を特徵抽出手法に，4 章において説明し た GMM を異常度算出手法として採用した，故障予測手法について説明する. 図 9 に提案手法の流れを示す. 本 手法は，2 章で述べたパワースペクトルを入力として LSTM-AEによる特徵抽出を行い，その後 GMMによる抽出 特徵からの異常度算出を行う。算出された異常度に対して閾值を設定し，一定期間閾値を超えた場合に故障が予測 
されるアラートを発生する，という流れである．実線の矢印で示した流れが異常度算出を行うためのモデルの学 習を行う段階 (学習フェーズ), 破線の矢印で示した流れが実際に故障予測を行う段階 (故障予測フェーズ) である.

入力データについて, LSTM-AE には振動データを変換することで得られるパワースペクトルを使用し，GMM への入力にはLSTM-AE の中間層より得られる中間表現を用いる. LSTM-AEへのパワースペクトルの入力は，パ ワースペクトル 320 次元を, 算出したフレーム単位で入力する. すなわち, 本論文において算出される異常度は, 表 1 に示したフレームシフトである $250 \mathrm{~ms}$ 毎に算出する. 本研究で利用している深層学習フレームワーク Keras では, LSTM-AE において，どれだけ前の時刻，すなわち前のフレーム分の情報を学習に用いるかを示す時間又 テップというハイパーパラメータを設定できる．後述する実験では，パワースペクトルの周波数領域情報 320 次 元, 時間ステップ 10 と設定している.これにより, LSTM-AE は 1 データに対し, 周波数方向には 320 次元, 時 間方向には $250 \mathrm{~ms} \mathrm{x} 10=2.5$ 秒分の情報を加味した学習・および推論を行うことが可能となる.

学習フェーズにおいては, 正常状態におけるデータ群のみからデータを選出して学習用データとして用いる.こ のことにより, モデルが正常状態におけるデータの分布を学習し, 正常状態のデータが入力されれば低い異常度 を，故障に近い状態のデータが入力されれば高い異常度を出力するように設計している.

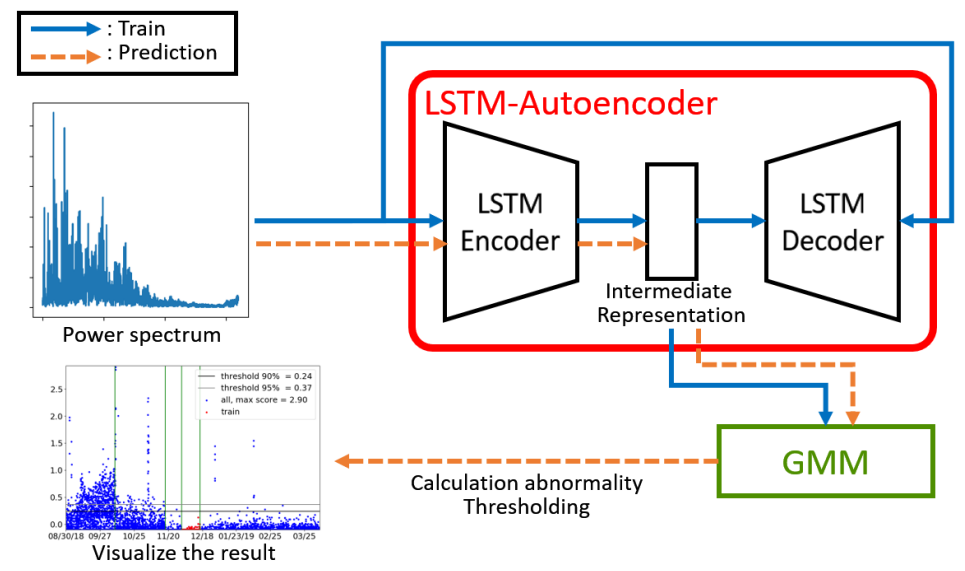

Fig. 9 The architecture of propose method. Our method consists of two models, LSTM-AE and GMM. LSTM$\mathrm{AE}$ is for extracting the feature of data, and GMM is for calculating the abnormality.

\section{$5 \cdot 1$ 学習フェーズ}

学習フェーズでは，はじめに LSTM-AE を学習し，その後 GMM の学習を行うという 2 段階での学習を行う．ま ず，LSTM-AEについて，入力層と出力ラベルの双方に振動データより得られたパワースペクトルを用いて学習す る. 続いて, 学習した LSTM-AE モデルに対して同様に学習データを入力し，中間層より得られる中間表現を取 得する，学習フェーズに用いるデータは正常状態のデータのみであるため, LSTM-AE の中間層より取得する中間 表現も正常状態のデータのみである。この中間表現データを用いて, GMM を学習し, 正常状態におけるデータの 分布を学習する. 最後に, 学習した 2 つモデルに対し, 後述する故障予測フェーズにおいて LSTM-AE の中間 表現が GMM の入力として伝播されるように設定する.

\section{2 故障予測フェーズ}

故障予測フェーズでは，学習フェーズと同様にパワースペクトルで学習を行ったモデルを用いて異常度を算出 した後, あらかじめ設定した閾值と比較して故障が近いかどうかを判定する. 学習済みモデルに対しパワースペ クトルを入力したとき, 正常なデータであれば異常度は低い值となり, 故障状態に近ければ近いほど異常度が高 くなる. しかし, センサ位置の変更や設備の一時停止など, 本研究で扱う劣化に伴う故障以外の突発的な変化が 起こった場合にも異常度が高くなる可能性があり, 必ずしも異常度が閾值を超えた場合に故障が近いとはいえな い.このことを踏まえ, 実装の際には, 突発的な変化に対してアラートを発生させないよう, 一定期間に対して 異常度の移動平均を算出し，この移動平均の值が閾值を超えた場合にアラートを発生させるように設計する. 
Asahi, Matsui, Tamura, Hayamizu, Isashi, Furukawa and Naitou,

Transactions of the JSME (in Japanese), Vol.86, No.891 (2020)

\section{6. 検 証 実 験}

提案した故障予測手法について，実際のモータに設置した振動データによる学習および異常度算出を行い，その 結果から故障予測を事前に行うことが可能であるか，かつその故障予測に頑健性があるかを検証する実験を行っ た. 2 章で述べた通り, データを取得した期間中には, 故障・チェーン交換・チェーンの初期伸びカット, データ の変化が発生しており, 本実験では全データのうちチェーンの初期伸びカット後の期間を正常状態として扱う.

\section{1 実験条件}

本実験を行うにあたり，設定すべきパラメータは，LSTM-AEにおける学習条件，GMMにおける条件，および 閾值の設定方法である．表 2 に各条件を示す．なお，本実験における LSTM-AE は Tensorflow (Abadi et al., 2016) をバックエンドとした深層学習フレームワーク Kerasにより設計されている.

Table 2 Settings of experimental condition for proposed method.

\begin{tabular}{c|c}
\hline Condition & Set value \\
\hline Number of data & $7452(500$ data for training $)$ \\
\hline Dimension of input \& output layer for LSTM-AE & 320 \\
\hline Time steps of LSTM blocks for LSTM-AE & 10 \\
\hline Dimension of intermediate layer for LSTM-AE & 128 \\
\hline Training epoch for LSTM-AE & 500 \\
\hline Optimizer of the model for LSTM-AE & RMSprop \\
\hline Demension of input for GMM & 128 \\
\hline Demension of output for GMM(= abnormality) & 1 \\
\hline Calculate the abnormality per & each frames \\
\hline Display the abnormality per & 50 \\
\hline Number of data for calculating simple moving average(SMA) & each data \\
\hline Threshold for diciding failure & and 95\% of whole data \\
\hline
\end{tabular}

本論文における異常度はフレーム毎に算出するが，後述する実験結果では，フレーム抽出した元データ毎に平均 を取ったデータを表示している．また，本実験で使用する移動平均は単純移動平均 (Simple Moving Average;SMA) であり, 以下の式 (13) で算出される.ただし， $t$ は移動平均を取る基準のデータの位置， $a\left(x^{(t)}\right)$ は移動平均をとる 異常度の基準のデータ, $k$ は移動平均の対象となるデータ数である. 本実験においては $k=50$, すなわち基準から 50 データ先までのデータによる移動平均を算出した。これは，時刻に換算すると約 5 時間分のデータの平均を算 出したことになる.

$$
\operatorname{SMA}\left(a\left(x^{(t)}\right)\right)=\frac{\Sigma_{t}^{t+k} a\left(x^{(t)}\right)}{k}
$$

さらに本実験においては，閾値として全体の異常度中の $90 \%$ と $95 \%$ の位置の 2 種類を設けている.これは, 2 種 類の閾值レベルのうち，どちらであればあらかじめ故障が予測できると判断できるかを検証するためである．こ こで, 本実験において上記のように閾値を設定する理由として, 使用する振動データの取得期間中に故障が発生 しており，故障期間を含めた全異常度をあらかじめ算出できるためであることを補足しておく．

\section{$6 \cdot 2$ 比較手法}

本論文における提案手法のモデル構成は, LSTM-AEによる特徵抽出, およびGMMによる異常度算出が重要な部分 を占める. 本手法と比較を行うための手法として, 特徵抽出手法には PCA, 異常度算出手法には Hotelling's T-Square 法を用いた。すなわち, 特徵抽出手法にはLSTM-AE と PCA を, 異常度算出手法には GMM と Hotelling's T-square 法の各 2 種類を組み合わせ, 合計 4 種類の手法による故障予測手法を実施した。今後, PCA と Hotelling's T-square 
法を組み合わせた手法を比較手法 1, PCA と GMM を組み合わせた手法を比較手法 2, LSTM-AE と Hotelling's T-square 法を組み合わせた手法を比較手法 3 と記す.

ここで，比較手法に用いた PCA および Hotelling's T-square 法に対する条件は以下の表 3 の通りである. なお， LSTM-AE，GMM，移動平均および閾值設定の条件は，先述した表 2 の通りである.

PCA ヘの入力データは, 提案手法と条件を揃えるため, 異常度を算出フレームとそれより前の 9 フレーム, 合 計 10 フレーム分のパワースペクトル 320 次元を用いている. すなわち, PCA の入力次元数は 3200 次元となる. また，使用するデータにおいて PCA を実施したところ，3200 次元の入力に対し第 9 主成分において累積寄与率が 95\%を超えるため, PCA の出力次元数を 9 次元としている.

Table 3 Settings of experimental condition for comparison.

\begin{tabular}{c|c}
\hline Condition & Set value \\
\hline Dimension of input for PCA & $3200(320 \mathrm{pt} \times 10$ frames $)$ \\
\hline Dimension of output of PCA & 9 \\
\hline Number of degree of freedom for Hotelling's T - square & $\begin{array}{c}128 \text { (for LSTM-AE feature) } \\
\text { (for PCA feature) }\end{array}$ \\
\hline Demension of output for Hotelling's T - square $(=$ abnormality) & 1 \\
\hline
\end{tabular}

\section{$6 \cdot 3$ 実験結果}

実験結果は，2 種類のグラフにより表示する.1 種類目は横軸を時間，縦軸をデータごとの異常度とした散布図， 2 種類目は横軸を時間, 縦軸を異常度の移動平均とした線グラフである. 本章では, 前者のグラフをグラフ (a), 後者をグラフ (b) と記す. グラフ (a) について, 1 個の点が 10 秒分のデータ 1 件の異常度の平均に相当する. 赤 い箇所が学習データの期間である。また，グラフ中には 4 本の縦線が引かれているが，これは左側より故障 (1), チェーン交換 (2), チェーンの初期伸びカット(3), データの変化(4) がそれぞれ発生した日に相当する. ここ で，実際のチェーンコンベアの挙動について，チェーンの初期伸びカット後は正常に作動していた。一方で，故 障前については, 故障が近づくにつれて挙動が正常時と異なるものになっていたほか, 故障後から初期伸びカッ ト前までの期間も，正常な状態とは挙動が若干異なっていた。また， 2 本の横線は，点線が $90 \%$ 閾值，実線が 95\%の閾值をそれぞれ示している.

提案手法による 2 種類のグラフを図 10 に示す。また，比較手法 $1,2,3$ による 2 種類のグラフを，順に図 11 , 図 12, 図 13 に示す.さらに，各手法における異常度算出結果において，チェーン交換の準備に要する 2 週間を基 準として, 故障 2 週間前から実際の故障が起こるまでの期間とその前の期間とを比較して異常度がどの程度上昇 するか, 手法間の比較を行った。同時間幅である故障 4 週間前-故障 2 週間前 (Period 1) と, 故障 2 週間前-故障直 前 $($ Period 2)の 2 区間における異常度の中央值を算出した結果，および 2 区間の中央值の比 (Period 2/Period 1) の 比較を図 14 に示す。ただし, 図 10 から図 13 においては, 突発的な異常度の上昇がどの程度現れるかも含めた異 常度の推移を確認することが目的であるため, 突発的な異常度の推移も計算に含まれる移動平均を使用した。一 方で，図 14 では期間中の異常度がどの程度増加するかを確認することが目的であり，平均值により算出した場合 は外れ值の影響を強く受けるため, その影響を軽減できる中央值を使用した。また，算出した異常度は平均 0 , 分 散 1 となるように正規化を行ったあと, 最小值が 0 になるように調整している. 学習データについては, 全デー タのうち 500 ファイル分を使用して学習したが, これは学習データ量としては十分確保されており, 異常度の推 移に支障をきたすような過学習は起きなかった。

\section{4 考察}

提示した 8 種類のグラフより, 提案手法および 3 種類の比較手法のすべての手法において, 計測開始直後から時 間に比例して異常度が上昇し, 故障が発生する 3 週間程度前には異常度の推移が 90\%の閾值を上回る結果が得ら れている.チェーン交換の準備に要する期間である 2 週間より前には異常度が高い值を維持することから，どの 手法を用いた場合においても, 劣化に伴う故障をあらかじめ予測することができるような異常度の推移となるこ 


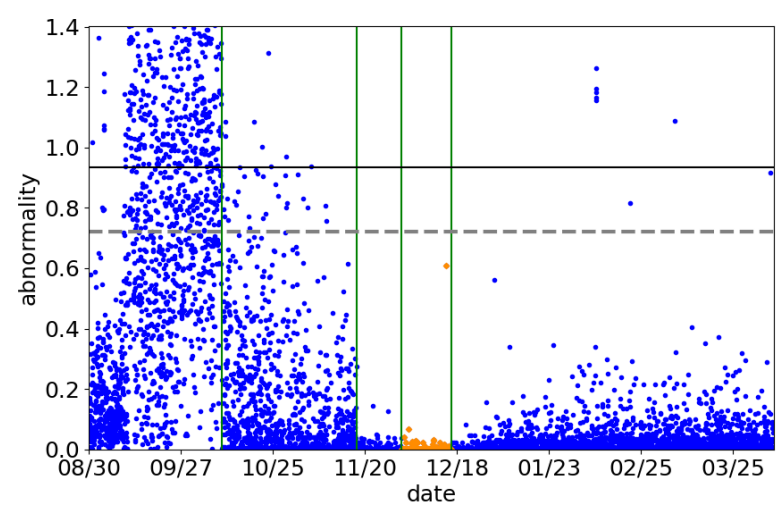

(a) The scatter plot of each data

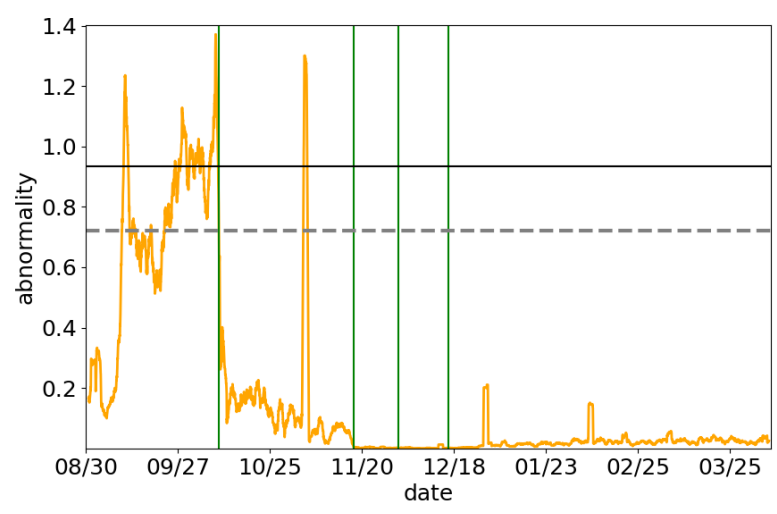

(b) The transition of simple moving average

Fig. 10 The scatter plot and the transition of simple moving average of abnormality with proposed method. The score of $90 \%$ threshold $=0.7225,95 \%$ threshold $=0.9351$, max score of abnormality $=4.0766$. We found that the results of abnormality calculated by all the methods, including the proposed and comparison methods, show a predictable transition of the failure in advance.

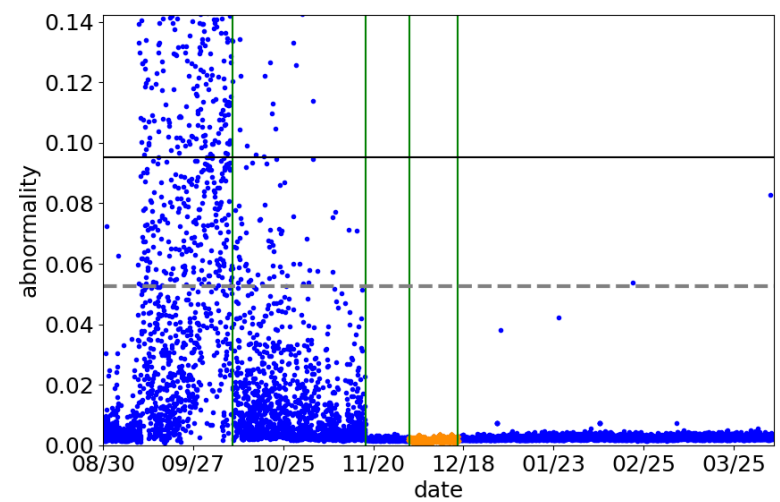

(a) The scatter plot of each data

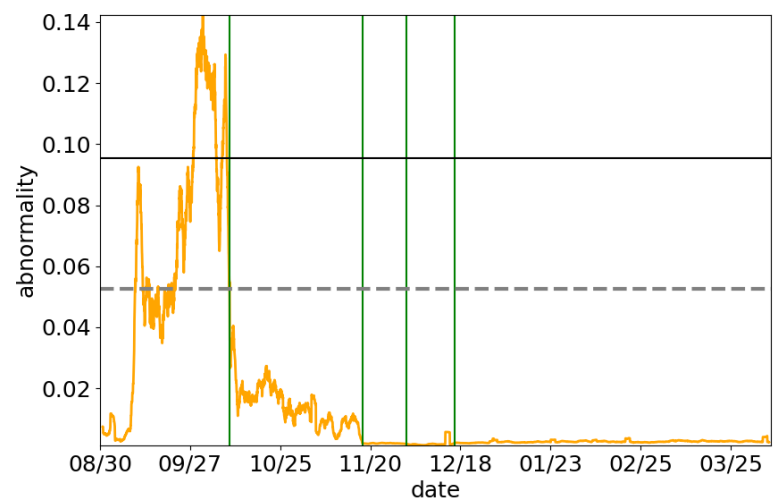

(b) The transition of simple moving average

Fig. 11 The scatter plot and the transition of simple moving average of abnormality with comparison method 1 (PCA+Hotelling's T-square). The score of $90 \%$ threshold $=0.0526,95 \%$ threshold $=0.0954$, max score of abnormality $=0.4388$.

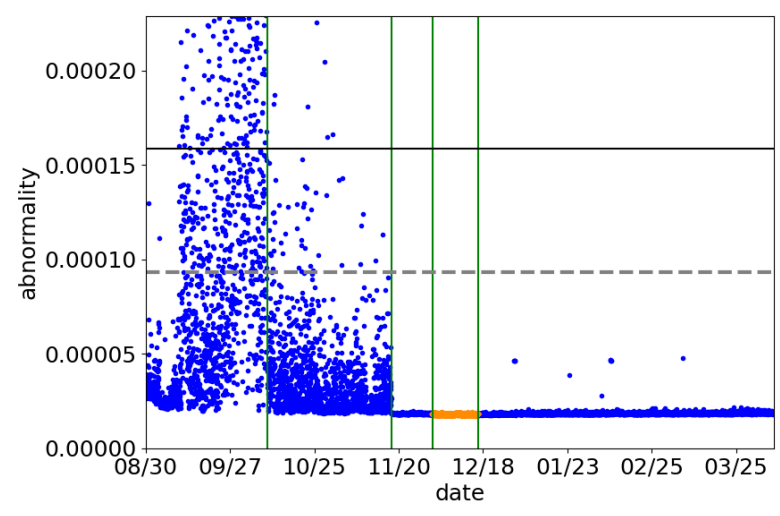

(a) The scatter plot of each data

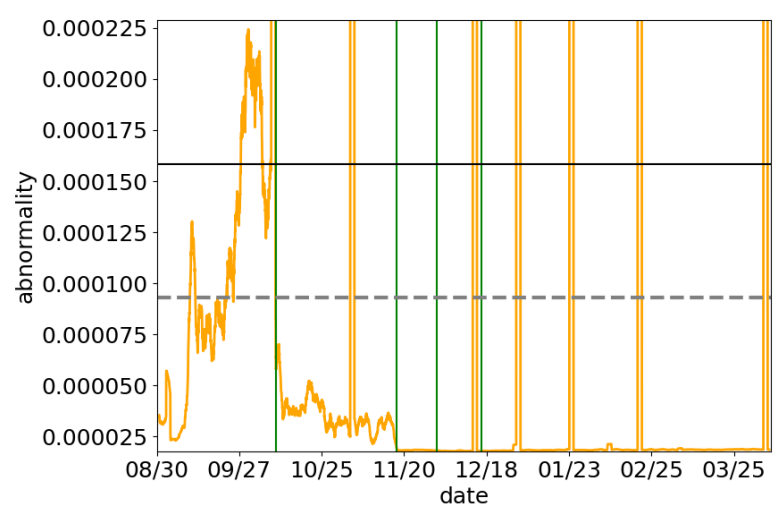

(b) The transition of simple moving average

Fig. 12 The scatter plot and the transition of simple moving average of abnormality with comparison method 2 (PCA+GMM). The score of $90 \%$ threshold $=0.0001,95 \%$ threshold $=0.0002$, max score of abnormality $=0.1731$. 


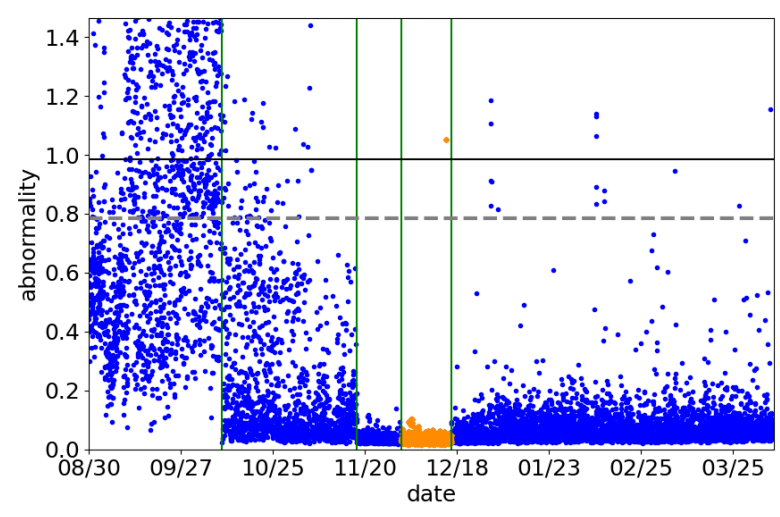

(a) The scatter plot of each data

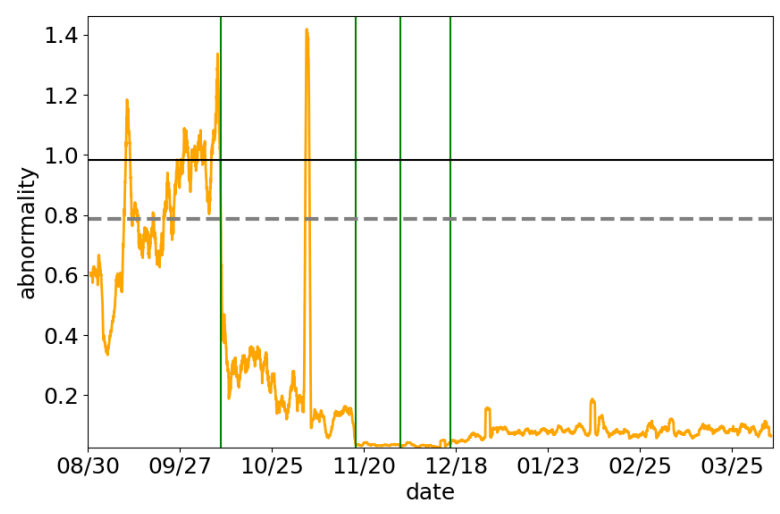

(b) The transition of simple moving average

Fig. 13 The scatter plot and the transition of simple moving average of abnormality with comparison method 3 (LSTM-AE+Hotelling's T-square). The score of $90 \%$ threshold $=0.7858,95 \%$ threshold $=0.9836$, $\max$ score of abnormality $=4.3055$.

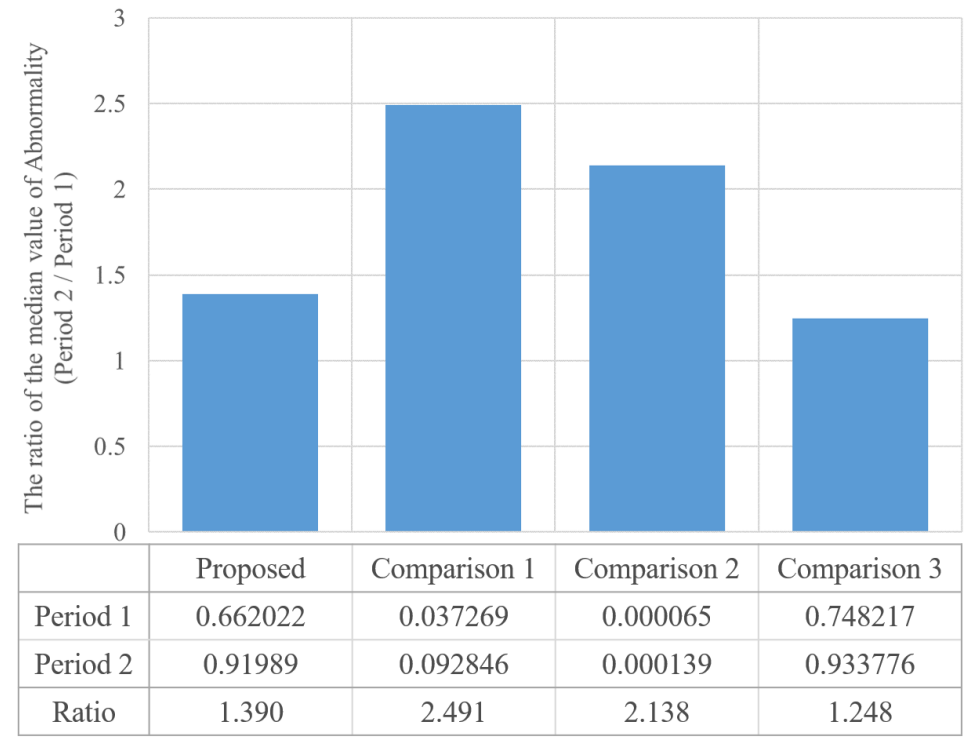

Fig. 14 Results of the median value of abnormality in two periods and the ratio of the median value of abnormality between Period 1 and Period 2 (Period 1 / Period 2). Period 1 corresponds to the data from four weeks before the failure to two weeks before the failure, and Period 2 corresponds to the data from two weeks before the failure to the failure. From this graph we found that the abnormality calculated with the feature extracted by PCA increased more rapidly just before the failure than the feature extracted by LSTM-AE.

とを示せた。一方で，比較手法 2 においては正常状態に含まれる，データの変化後の期間中に複数回突発的に閾 值を大きく上回っている箇所が現れた。また，故障後からチェーン交換までの期間中に，比較手法 1 以外の 3 種 類の手法において，突発的に閾值を大きく上回る箇所が確認できた。この現象は，データを収集する加速度セン サ自体の変化に起因する外れ值であると考えられ，突発的な異常度上昇を抑える処理を加えることにより解決で きる．しかし，突発的な異常度上昇の頻度が増加した場合に，頑健な故障予測に影響を及ぼす一要因となりうる ことが考えられる.

続いて，それぞれの故障予測手法の結果の比較を行い，その頑健性に関する詳細な考察を行う.

はじめに，異常度算出を行う手法である Hotelling's T-square 法と GMM に対する異常度の推移について比較す る. 特徵抽出手法が同じである場合， 2 種類の異常度算出手法において異常度の移動平均のグラフより大きく差 がみられるような箇所はなかったが，先述した通り異常度の突発的な上昇が GMMによる手法では現れた一方， Hotelling's T-square 法ではこの傾向をある程度抑えられた。しかしながら特徵抽出をLSTM-AEで行った場合にお いて, 突発的な異常度のピークではなく，時間変化に伴う異常度の推移を見た場合には, Hotelling's T-square 法の 場合には区間の変更直後から異常度が上昇し, 全体的に 0.1 付近まで上昇しているのに対し, GMMの場合には区 
間の変更直後における異常度の上昇は起きず，データ集計終了時点での異常度も小さい值を維持している．この ことから，突発的な異常度の上昇を抑えながら，正常な期間におけるデータと故障前におけるデータの間の異常 度の推移に差が出る，より頑健な故障予測を行うためには, GMM と Hotelling's T-square 法を統合した手法を考案 する必要があると考えられる.

次に，特徵抽出手法である LSTM-AE と PCA に対する異常度の推移について比較する. 先述した通り，異常度 の推移については，LSTM-AE と PCA 双方とも同様であることがわかった。一方で，異常度より算出された閾值 を比較すると，PCA の場合は 90\%の閾值と 95\%の閾值の幅が，0\%から 90\%までの幅とほぼ同程度であった．故 障前の推移についても，LSTM-AE の場合は一部大きく下がる箇所があるものの徐々に異常度が 90\%の閾値を上 回り, 故障 2 週間前-故障区間では 95\%の閾值付近を前後するように推移しているのに対し, PCA の場合は急激

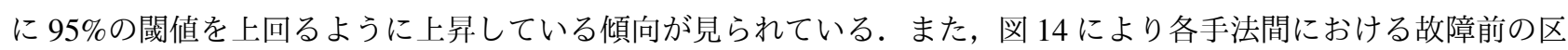
間の異常度の変化の割合を比較したところ，LSTM-AE で特徵を抽出した提案手法では 1.3895 ，比較手法 3 では 1.2480 と, 異常度が徐々に上昇していたことを示したのに対し, PCA で特徵を抽出した比較手法 1 では 2.4912, 比較手法 2 では 2.1385 となり, 異常度が 2 倍以上に上昇していることが分かった。この急激な異常度の上昇によ り，正常時や故障 2 週間前の異常度と故障直前の異常度において大きく差が生じたことが，PCA の場合において 90\%の閾值から 95\%の䦐值と0\%から 90\%の閾值の幅がほぼ同程度となった原因である．これらのことから，PCA により特徵抽出した異常度算出結果は, 故障が発生する 2 週間前から故障直前までの異常度とそれ以前を比較し た場合，LSTM-AEによる特徴抽出よりも大きく変化していた，といえる.

本研究においては, 図 3 で示すような異常度の推移, すなわち故障前においても異常度が徐々に増加し, 故障 が発生する一定期間前から異常度が閾值を上回るような推移となる異常度算出モデルが，チェーンコンベアの劣 化を予測する上では望ましい推移である。このため, LSTM-AEによる異常度算出結果は, PCA よりも理想的な 異常度の推移に近しいものであったと考えられる.

このような異常度の推移が得られた理由として, LSTM-AE が周波数情報と時間情報を効率的に学習し, かつ非 線形な次元圧縮な特徵抽出ができるため, 線形的な次元圧縮手法である PCA よりも表現力の高い特徵量の抽出に 成功しており，よりチェーンコンベアの状態を反映した異常度の算出が行えていると考えられる.このことから， 故障を直前に発見することを想定した場合には LSTM-AE と PCA 双方有効であるが， 1 章で定義したような「頑 健な」故障予測を行う場合には，閾值の幅や推移の上下幅を見るとLSTM-AEによる特徵抽出が有効であるとい える.

\section{7. 結言}

本論文では，工場設備の故障を，加速度センサから得られる振動データに対し，機械学習手法を用いて予測す る手法を提案した，機械学習手法である GMM を用いて，あまり発生しない異常な挙動を，異常度という数值に より表現し，閾值を定めることで故障をあらかじめ予測できるように設計した．また，特徵抽出には深層学習了 ルゴリズムの一種である再帰型オートエンコーダ，LSTM-AEを用いることで，従来の異常検知手法では捉えにく いような非線形かつ時系列情報を持つパターンを学習できるよう設計した。

実際の機械設備より取得した振動データを用いて検証実験を行った結果，実際の故障から一定期間前には異常度 が閾值を超える傾向が見られ，提案手法によって故障をあらかじめ予測できたことを示した．また，特徵抽出手 法について，従来手法である PCAによる特徴抽出を行った場合と異常度算出結果の推移を比較したところ，どの 手法を用いた場合においても，故障をあらかじめ予測することができるような異常度の推移となることが分かっ た。一方で，異常度の推移および異常度の割合より設定される閾值について考察した結果，LSTM-AE が従来の線 形な特徴抽出手法よりも高い表現力をもつ特徵抽出を行うことが可能であることを示した。これにより，従来手 法に対する，故障予測モデルの頑健性に関する提案手法の優位性を示した.

更に頑健な故障予測手法を構築するにあたって，以下の 2 種類の課題が存在する．1 1 目は，特徵抽出手法に対 するさらなる構造およびパラメータ調整が必要という点である．検証実験の結果において現れている通り，正常 なデータ群の期間中においても，閾值よりは低いが突発的に異常度が閾值を上回る箇所が発生している．この傾 向を抑えるため, LSTM-AE の構造の調整や GMM のパラメータ調整，GMM と Hotelling’s T-square 法を統合した 
異常度算出手法の考案など, さらなる研究が必要である. 2 つ目は, 提案手法の end-to-end 化である. end-to-end とは, データの変換や出力結果の調整等の必要ない構造のことを示し, 生データをモデルに入力するだけで結果 が出力される，というモデルである．本手法は 2 段階の構成を採用しているが，実環境下で使用しやすくするた め, end-to-end モデル化する必要があると考えられる.

\section{文献}

Abadi, M., Barham, P., Chen, J., Chen, Z., Davis, A., Dean, J., Devin, M., Ghemawat, S., Irving, G., Isard, M., Kudlur, M., Levenberg, J., Monga, R., Moore, S., Murray, D. G., Steiner, B., Tucker, P., Vasudevan, V., Warden, P., Wicke, M., Yu, Y. and Zheng, X., TensorFlow: a system for large-scale machine learning, Proceedings of the 12th USENIX conference on Operating Systems Design and Implementation (OSDI) (2016), pp.265-283.

Abdi, H. and Williams, L. J., Principal component analysis, Wiley interdisciplinary reviews: computational statistics, Vol.2, No.4 (2010), pp.433-459.

Baldi, P., Autoencoders, unsupervised learning, and deep architectures, Proceedings of the International Conference on Machine Learning (ICML) workshop on unsupervised and transfer learning (2012), pp.37-49.

Chalapathy, R. and Chawla, S., Deep learning for anomaly detection: a survey, arXiv preprint arXiv:1901.03407(2019).

Gers, F. A., Schmidhuber, J. and Cummins, F., Learning to forget: continual prediction with LSTM, Neural computation Vol.12, No.10 (2000), pp.2451-2471.

Hasegawa, T., Ogata, J., Murakawa, M., Kobayashi, T. and Ogawa, T., Adaptive training of vibration-based anomaly detector for wind turbine condition monitoring, Proceedings of the Annual Conference of the Prognostics and Health Management Society 2017, Vol.8 (2017), pp.177-184.

Hochreiter, S. and Schmidhuber, J., Long short-term memory, Neural computation, Vol.9, No.8 (1997), pp.1735-1780. 井手剛, 杉山将, 異常検知と変化検知, 講談社 (2015).

Keras Documentation (online), avaliable from〈https://keras.io/〉, (参照日 2019 年 12 月 23 日).

近藤稔, 振動のオクターブバンド分析を用いた異常検知法による車両機器の診断, 日本機械学会論文集, Vol.84, No.862

(2018), DOI:10.1299/transjsme.17-00594.

中塚俊介, 相澤宏旭, 加藤邦人, 少数不良品サンプル下における Adversarial AutoEncoder による正常モデルの生成と 異常検出, 精密工学会誌, Vol.84, No.12 (2018), pp.1071-1078.

西田勇, 立川宗治, 佐藤隆太, 白瀬敬一, 切削トルクの予測結果と実測結果の定量比較による加工異常検出システム (第 1

報 工具摩耗による加工異常検出), 日本機械学会論文集, Vol.84, No.857 (2018), DOI:10.1299/transjsme.17-00433. 岡谷貴之, 機械学習プロフェッショナルシリーズ 深層学習, 講談社 (2015).

Srivastava, N., Mansimov, E. and Salakhudinov, R., Unsupervised learning of video representations using lstms, International conference on machine learning(2015), pp.843-852.

Werbos, P. J., Backpropagation through time: what it does and how to do it, Proceedings of the Institute of Electrical and Electronics Engineers (IEEE), Vol.78, No.10 (1990), pp.1550-1560.

\section{References}

Abadi, M., Barham, P., Chen, J., Chen, Z., Davis, A., Dean, J., Devin, M., Ghemawat, S., Irving, G., Isard, M., Kudlur, M., Levenberg, J., Monga, R., Moore, S., Murray, D. G., Steiner, B., Tucker, P., Vasudevan, V., Warden, P., Wicke, M., Yu, Y. and Zheng, X., TensorFlow: a system for large-scale machine learning, Proceedings of the 12th USENIX conference on Operating Systems Design and Implementation (OSDI) (2016), pp.265-283.

Abdi, H. and Williams, L. J., Principal component analysis, Wiley interdisciplinary reviews: computational statistics, Vol.2, No.4 (2010), pp.433-459.

Baldi, P., Autoencoders, unsupervised learning, and deep architectures, Proceedings of the International Conference on Machine Learning (ICML) workshop on unsupervised and transfer learning (2012), pp.37-49.

Chalapathy, R. and Chawla, S., Deep learning for anomaly detection: a survey, arXiv preprint arXiv:1901.03407(2019). 
Gers, F. A., Schmidhuber, J. and Cummins, F., Learning to forget: continual prediction with LSTM, Neural computation Vol.12, No.10 (2000), pp.2451-2471.

Hasegawa, T., Ogata, J., Murakawa, M., Kobayashi, T. and Ogawa, T., Adaptive training of vibration-based anomaly detector for wind turbine condition monitoring, Proceedings of the Annual Conference of the Prognostics and Health Management Society 2017, Vol.8 (2017), pp.177-184.

Hochreiter, S. and Schmidhuber, J., Long short-term memory, Neural computation, Vol.9, No.8 (1997), pp.1735-1780.

Ide, T. and Sugiyama, M., Anomaly detection and change detection, Kodansha (2015) (in Japanese).

Keras Documentation (online), avaliable from 〈https://keras.io/〉, (accessed on 23 December, 2019).

Kondo, M., Machine diagnosis for railway vehicle equipment using anomaly detection method with octave band vibration spectra, Transactions of the JSME (in Japanese), Vol.84, No.862 (2018), DOI:10.1299/transjsme.17-00594.

Nakatsuka, S., Aizawa, H. and Kato, K., Generation of normal model and discrimination of defect by adversarial autoncoder under small number of defective samples, Journal of the Japan Society of Precision Engineering, Vol.84, No.12 (2018), pp.1071-1078 (in Japanese).

Nishida, I., Tatekawa, M., Sato, R. and Shirase, K., Cutting trouble detection system based on quantitative comparison between predicted and measured cutting torques (1st report cutting trouble detection for tool wear), Transactions of the JSME (in Japanese), Vol.84, No.857 (2018), DOI:10.1299/transjsme.17-00433.

Okatani, T., Machine lerarning professional series: deep learning, Kodansha (2015) (in Japanese).

Srivastava, N., Mansimov, E. and Salakhudinov, R., Unsupervised learning of video representations using lstms, International conference on machine learning(2015), pp.843-852.

Werbos, P. J., Backpropagation through time: what it does and how to do it, Proceedings of the Institute of Electrical and Electronics Engineers (IEEE), Vol.78, No.10 (1990), pp.1550-1560. 